\section{Kidney \\ Blood Pressure Research}

\title{
Kinetics of Hepatitis B Virus Load During Haemodialysis Sessions and $\alpha$-Interferon: A Prospective Study
}

\author{
Fabrizio Fabrizi $^{a}$ Giovanna Lunghic Giancarlo Alongi ${ }^{d}$ Filippo Aucella ${ }^{\mathrm{e}}$ \\ Francesco Barbisonif Sergio Bisegnag Stefano Mangano ${ }^{\text {h }}$ \\ Giorgio Romei-Longhena' ${ }^{i}$ Andrea Artoni ${ }^{b}$ Giuseppe Bettoni ${ }^{\text {b }}$ \\ Piergiorgio Messa ${ }^{a}$ Paul Martinj
}

${ }^{a}$ Division of Nephrology, ${ }^{b}$ Division of Internal Medicine, Institute of Preventive Medicine, Maggiore Hospital, IRCCS Foundation, Milano, Italy; 'Dialysis Units at Zingonia, eSan Giovanni Rotondo, 'Lodi,

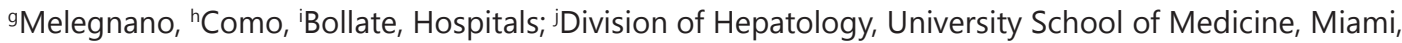
FL, USA

\section{Key Words}

Hepatitis B Virus (HBV) • Hemodialysis • HBV viremia • HB surface antigen (HBsAg)

\begin{abstract}
Background: It has been reported a slow progression of hepatitis B in patients undergoing maintenance dialysis, and a role of dialysis session per se has been suggested. The aim of the present study is to evaluate the kinetics of the hepatitis B viral load (HBV DNA) in serum during haemodialysis sessions using a highly sensitive technique; the role of interferon- $\alpha$ in lowering HBV viral load in such patients was also investigated. Methods: HBV DNA was determined in $24 \mathrm{HBsAg}$ positive patients on maintenance hemodialysis immediately before and after a 4-hour hemodialysis session, the same measurements were repeated 48 and 72 hours later. HBV DNA quantitation was performed by a novel RealTime PCR assay. Serum IFN- $\alpha$ levels were tested in parallel in a subset of HD sessions $(n=40)$ by ELISA. Results: 20 (83\%) HBsAg positive patients had detectable HBV DNA in serum. Positive status for HBV DNA in serum was not predicted by demographic, clinical or biochemical parameters. HBV load decreased in many patients after hemodialysis sessions, $5.92 \log _{10} \mathrm{IU} / \mathrm{mL}\left(95 \% \mathrm{CI}, 5.34\right.$ to $6.28 \log _{10} \mathrm{IU} /$ $\mathrm{mL})$ vs. $4.79 \log _{10} \mathrm{IU} / \mathrm{mL}\left(95 \% \mathrm{CI}\right.$, 4.23 to $\left.6.15 \log _{10} \mathrm{IU} / \mathrm{mL}\right)(P=0.02)$. A significant relationship between mean HBV DNA levels before dialysis and percentage reduction of HBV DNA during HD sessions occurred [ $F$-test $=5.41$, rho (least squares) $=0.307]$. Increase of serum IFN- $\alpha$ levels was found in a minority $(3 / 40=7 \%)$ of HD sessions. Conclusions: Hemodialysis procedure gives reduction of HBV load in HBsAg chronic carriers; no relationship with IFN- $\alpha$ activity during HD sessions was found. The kinetics of HBV viremia in HD procedures could explain the low viral load which is typically observed in these patients. Further studies to identify the mechanisms responsible for reduction of HBV viremia during HD procedures are under way.
\end{abstract}

Copyright (C) 2013 S. Karger AG, Basel

Fabrizio Fabrizi, M.D.

Division of Nephrology, Maggiore Hospital, IRCCS Foundation, Pad. Croff, via Commenda 15, 20122 Milano (Italy)

Tel. (39 2) 55034552, Fax (39 2) 55034550, E-Mail fabrizi@policlinico.mi.it 


\section{Kidney Blood Pressure Research}

\section{Introduction}

The frequency of HBV infection is now low in dialysis units in the developed world with prevalence of chronic HBsAg seropositive patients ranging from $0 \%$ to $10 \%$ in long-term dialysis population [1-2]. Outbreaks of HBV infection, however, continue to be reported in dialysis units with some cases of severe acute hepatitis and even death [3-4]. The epidemiology of HBV among dialysis patients in the less-developed world is not well known; there are scattered reports concerning typically single-center surveys with rates of chronic HBsAg seropositivity ranging between $2 \%$ and $20 \%$ [5-9].

Only limited information exists on the natural history of HBV infection in patients with chronic kidney disease (CKD) including dialysis patients [10-14]. An accurate assessment of the natural history of HBV in dialysis patients is difficult to obtain as HBV is usually asymptomatic with an apparent indolent course. The disease course of HBV extends over decades rather than years, whereas CKD patients have higher morbidity and mortality rates than those of the general population due to age and comorbidity conditions, making the long-term consequences of HBV infection difficult to establish. Patients with advanced CKD have evidence of immune compromise at both B- and T-cell level. The disease course of hepatitis B in patients on maintenance dialysis is indolent and the reduced immune competence of dialysis patients has been suggested as a possible explanation for decreased necroinflammatory response to HBV infection in these patients [15]. Also, the virological features of HBV among patients on regular dialysis could play a role- it appears that the hepatitis B viral load in serum is rather low and haemodialysis sessions reduce HBV DNA titers in these patients [16-21]. Various mechanisms have been cited including clearance of HBV viremia during hemodialysis sessions [22-23] or peritoneal dialysis treatment [24]. The intradialytic production of interferon (IFN) [25] or other protective substances [26] has been advocated for HCV-infected patients on intermittent dialysis.

The aim of this prospective study was to evaluate if HBV viral load declines during hemodialysis procedures; a highly sensitive assay for HBV DNA quantitation being used. The role of intradialytic kinetics of interferon- $\alpha$ in the drop of HBV DNA during HD sessions was also addressed.

\section{Patients and Methods}

\section{Study Group}

All chronic HBsAg carriers undergoing maintenance haemodialysis in seven units in Italy were prospectively included. The patients $(n=24)$ underwent long-term haemodialysis (3- or 4-hour treatments; three times weekly), and signed an informed consent; the study protocol was approved by the local ethic review boards. The patients included in the study fulfilled the following criteria; (1) absence of anti-human immunodeficiency virus antibody, (2) exclusion of other causes of chronic liver disease (alcohol, hepatotoxic drugs, autoimmune chronic hepatitis, hemochromatosis, Wilson disease, and alpha-antitrypsin deficiency), and (3) absence of antiviral treatment including $\alpha$-interferon based therapy.

\section{Methods}

All plasma samples were promptly stored at $-70^{\circ} \mathrm{C}$ within four hours of sample collection in aliquots until tested by the Abbott RealTime PCR assay; each sample was thawed only for testing. HBsAg was assayed by radioimmunoassay using commercially available kits (Abbott Laboratories). Serum samples were tested for HBV e antigen (HBeAg) and the respective antibody (HBeAb) by radioimmunoassay using available tests (Abbott Laboratories). Serum aspartate aminotransferase (AST; also known as serum glutamic oxaloacetic transaminase) and alanine aminotransferase (ALT; also known as serum pyruvic oxaloacetic transaminase) levels were measured using standard automated analyzers. Upper limits in both the AST (SGOT) and ALT (SGPT) assays were $45 \mathrm{IU} / \mathrm{L}$. All patients were screened by third-generation enzyme-linked immunosorbent assay (anti-HCV 3.0 ELISA; Ortho Diagnostic Systems, Raritan, NY) that detects antibodies (immunoglobulin $\mathrm{G}[\mathrm{IgG}]$ ) to proteins derived from three distinct regions of the hepatitis C virus (HCV) genome (c22-3, c200). 


\section{Kidney \\ Blood Pressure Research}

All tests were performed and interpreted strictly in accordance with the manufacturers' instructions. We recorded the pre- and post-dialysis body weight of the HD sessions evaluated in the study.

Virology

Hepatitis B virus DNA quantitation was performed by a new real-time PCR (Abbott RealTime). The Abbott RealTime HBV test (Abbott Laboratories, USA) is an in vitro real-time polymerase chain reaction (PCR) assay for the quantification of HBV DNA in human plasma from HBV-infected individuals [27]. The target region is in the $N$ terminal third of the surface gene ensuring that the assay is not impacted by YMDD mutants, HBsAg escape mutants, or drug resistant mutants, as this region is essential for the assembly and secretion of subviral particles, and tolerates only minor structural changes. The Abbott RealTime HBV performances are as follows: Sensitivity, $10 \mathrm{IU} / \mathrm{mL}$; Linear Range, $10 \mathrm{IU} / \mathrm{mL}$ (1.0 log IU/mL) to 1 billion IU/ mL (9.0 log IU/mL); Inter-Assay Standard Deviation <or=to $0.25 \log$ IU/mL; Specificity, 100\%; Genotype Detection, accurate quantification of genotypes A, B, C, D, E, F, G, H; Specimen type, serum and plasma; Standardization, World Health Organization (WHO) international standard for hepatitis B virus DNA; Internal Control: added to lysis buffer during extraction and detected to all levels [28].

At the end of the longer (72 hours) interdialytic period, each patient underwent a 4-hour dialysis session. Blood samples were collected from a peripheral vein immediately before the beginning (dialyser empty) and the end of dialysis for determination of HBV DNA levels. Additional blood samples were collected during the subsequent dialysis sessions (mid-week and end-week, respectively)- immediately before and after the dialysis session.

A subset $(n=12)$ of patients was tested at baseline for detection of precore and core mutations. Detection of gene promoter polymorphism in nucleotides 1762 and 1764 (basal core promoter, BCP) and nucleotides 1896 (HBV precore) was performed by Inno-Lipa HBV Precore Assay (Innogenetics; Ghent, Belgium).

\section{Interferon measurements}

In a subset of HD sessions $(n=40)$, we measured recombinant human interferon -alpha (IFN- $\alpha$ ) in serum. Twenty patients were analyzed (two hemodialysis sessions for each patient). We used an enzymelinked immunosorbent assay for detection of IFN- $\alpha$ in serum (Human IFN- $\alpha$ Instant ELISA). The molecular weight of the recombinant human IFN- $\alpha$ is about $19 \mathrm{kDa}$ consisting of 166 (165 for IFN- $\alpha 2 \mathrm{a}$ ) amino acid residues lacking any $\mathrm{N}$-glycosylation ( $\alpha 14$ has $\mathrm{N}$-glycosylation). The IFN- $\alpha$ product is manufactured from Pestka Biomedical Laboratories, Inc. (PBL InterferonSource, Piscataway, NJ, US) solely for research use. Samples were not run within 24 hours but were stored frozen at $-20^{\circ} \mathrm{C}$ to avoid loss of bioactive human IFN- $\alpha$; repeated freeze-thaw cycles were not made. Semiquantitative measurement of human IFN- $\alpha$ was performed.

\section{Statistical analysis}

Serum HBV DNA values and aminotransferase levels were logarithmically $\left(\mathrm{L}_{10}\right)$ transformed to obtain normal distribution and then subjected to statistical tests. The Shapiro-Wilk test was used to assess that the samples came from a normally distributed population. Serum HBV DNA values by Abbott RealTime Assay and aminotransferase values are expressed as mean \pm SD or median values with respective range or $95 \%$ confidence intervals (CIs). Means between two groups were compared using Student's $t$-test. Student's $t$-test (paired data) was used to compare serum HBV DNA levels at the beginning versus the end of hemodialysis (HD) sessions. Categorical data were compared by chi-squared test with Yates' correction for continuity. All $P$ are two sided, and $P$ less than 0.05 was considered significant. Simple linear regression analysis was used to analyse the relationship between mean HBV DNA levels before dialysis and the percentage reduction of HBV DNA after HD session. Statistical analysis was performed using the Free Statistics Software (version 1.1.23r7), Office for Research Development and Education, URL http://www.wessa.net/ by Wessa P. (2012). .

\section{Results}

The demographic data of the study patients are shown in Table 1. Fourteen patients underwent chronic HD using polysulphone membrane, four by polymethylmetacrylate, 


\section{Kidney \\ Blood Pressure Research}

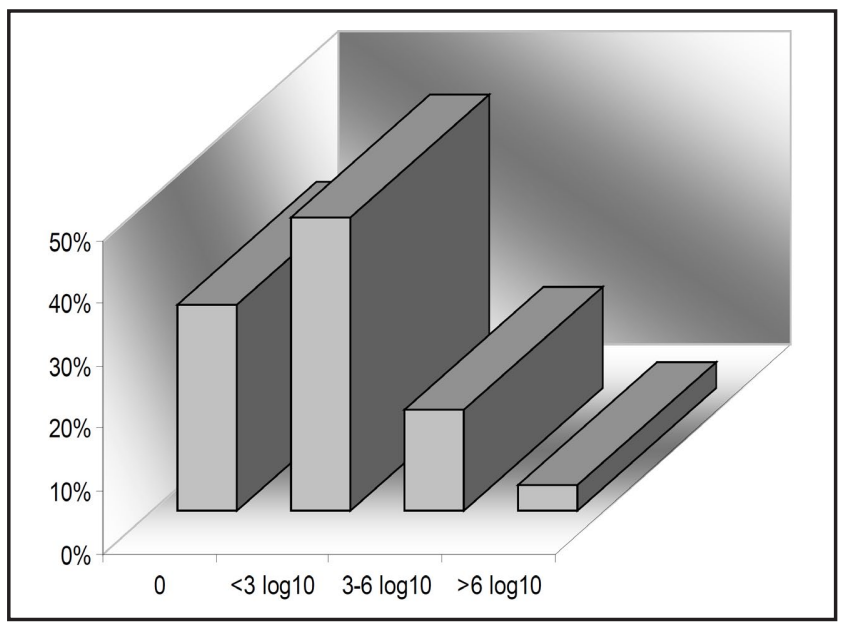

Fig. 1. Distribution of HBV viral $\operatorname{load}\left(\log _{10} \mathrm{IU} / \mathrm{mL}\right)$ among HBsAg positive patients ( $n=24,70$ haemodialysis sessions) before HD.

Fabrizi et al.: HBV Viremia and Dialysis
Kidney Blood Press Res 2013;37:286-294

DOI: 10.1159/000350156

C 2013 S. Karger AG, Basel

www.karger.com/kbr

Table 1. Characteristics of patients included in the study group $(n=24)$

\begin{tabular}{lc}
\hline Characteristics & $(\mathrm{n}=24)$ \\
\hline Age, years & $59.9 \pm 14.7$ \\
Time on dialysis, months & $127.6 \pm 102$ \\
Gender, female (\%) & $5(20.8 \%)$ \\
Race, Caucasian & $23(96 \%)$ \\
Creatinine, mg/dL & $9.4 \pm 3.6$ \\
SGOT, UI/L & $25.7 \pm 26.1$ \\
SGPT, UI/L & $26 \pm 44.09$ \\
GGT, UI/L & $63 \pm 94$ \\
Total protein (g/dL) & $7.4 \pm 0.7$ \\
Albumin (g/dL) & $5.7 \pm 0.8$ \\
Bilirubin (mg/dL) & $0.34 \pm 0.7$ \\
\hline
\end{tabular}

Data presented as mean \pm standard

three by hemophane, and three by polyacrylonitrile. Data of 70 haemodialysis sessions were collected.

Causes of ESRD were as follows: nephroangiosclerosis ( $n=5)$, chronic glomerulonephritis $(n=6)$, diabetic nephropathy $(n=2)$, polycystic kidney disease $(n=1)$, chronic pyelonephritis $(n=4)$, and ESRD of unknown or other causes $(n=6)$. The frequency of HBsAg positive patients with detectable HBV viremia in serum was $20 \%(20 / 24)$; the rate of $\mathrm{HBsAg}$ positive/HBeAg positive individuals was $8.3 \%(2 / 24)$. Positive anti-HCV serologic status was reported in two patients (8\%).

There was a significant drop of HBV viral load at the end of HD session- mean HBV DNA levels at the beginning and the end of HD sessions were $5.92 \log _{10} \mathrm{IU} / \mathrm{mL}$ ( $95 \% \mathrm{CI}, 5.34$ to 6.28 $\log _{10} \mathrm{IU} / \mathrm{mL}$ ) vs. $4.79 \log _{10} \mathrm{IU} / \mathrm{mL}\left(95 \% \mathrm{CI}, 4.23\right.$ to $\left.6.15 \log _{10} \mathrm{IU} / \mathrm{mL}\right)$, respectively $(P=0.02)$. The mean HBV DNA levels in the subgroup of HBsAg positive patients with detectable HBV DNA in serum were $5.96 \log _{10} \mathrm{IU} / \mathrm{mL}\left(95 \% \mathrm{CI}, 5.32\right.$ to $\left.6.28 \log _{10} \mathrm{IU} / \mathrm{mL}\right)$ (before HD sessions). The majority of patients had pre-dialysis HBV DNA titers under $\log _{10} \mathrm{IU} / \mathrm{mL}(67 / 70=95.7 \%)$ (Figure 1).

HBV DNA reduction occurred in many HD sessions [42\% (29/70)], irrespective of dialysis membrane, patient characteristics, or HD session (mid-week, end-week hemodialysis or 72 hours after). Four HBsAg positive HBV DNA negative patients underwent twelve HD procedures without detectable HBV DNA in serum before/after HD session. Identical HBV DNA titers were found in nine patients (9/70=13\%); an increase in HBV DNA levels at the end was observed in $20 \mathrm{HD}$ procedures (28\%). The mean percentage reduction of HBV viral load at the end of HD session compared with the beginning was around $26.3 \% \pm 12.5 \%$.

Figure 2 shows mean HBV titers before/after each HD session (mid-week, end-week or 72 hours after, respectively). Mean HBV titers at pre-dialysis phase were higher in the HD session at the beginning of the week than the mid-or end-week procedures, even if no significant differences occurred $(P=0.62)$. We found a significant relationship between mean HBV DNA levels at the start of dialysis and percentage drop of HBV DNA during HD sessions occurred [simple linear regression-analysis of variance: $F$-test=5.418026, rho (least squares) $=0.307$ ] (Figure 3 ).

A decrease of serum IFN- $\alpha$ levels in 15 (37.5\%) HD sessions was noted, 22 (55\%) HD procedures did not show modifications of IFN- $\alpha$ concentration. An increase of serum IFN- $\alpha$ levels was found in three (7.5\%) HD sessions. We did not observe relationship between HBV DNA reduction during HD procedure and IFN kinetics (data not shown) by the analysis of a subset $(n=40)$ of HD sessions. No PC/BCP mutations were detected. 


\section{Kidney Blood Pressure Research}

Fig. 2. HBV DNA titers $\left(\log _{10} \mathrm{IU} / \mathrm{mL}\right)$ before/ after haemodialysis at each session.

Fig. 3. HBV DNA levels and percentage reduction of HBV DNA during HD procedures.

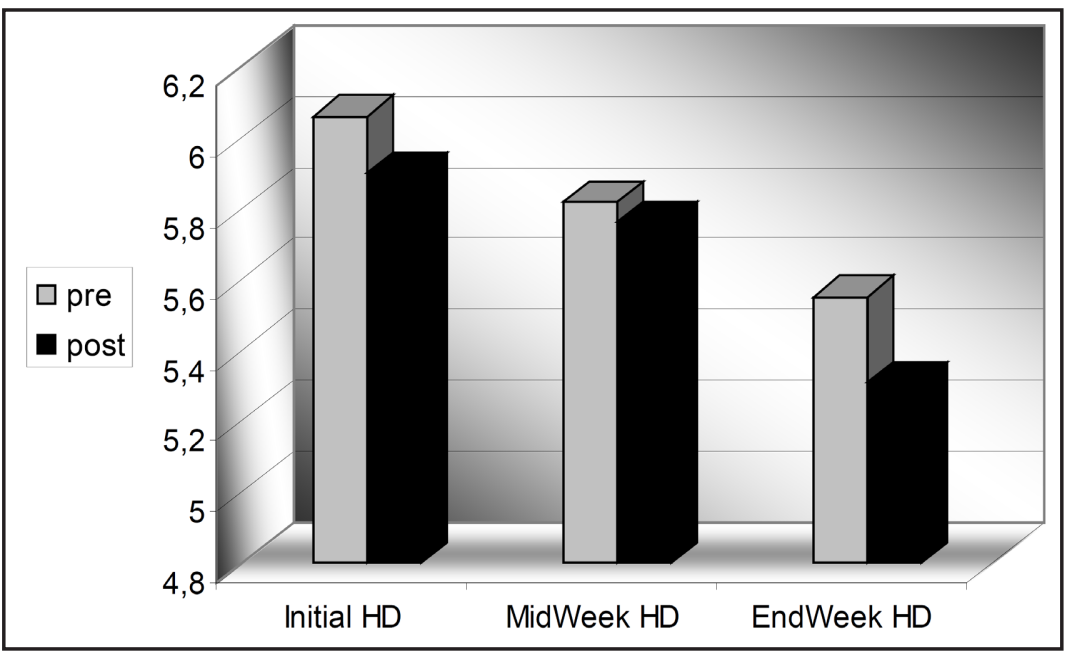

$\nabla$

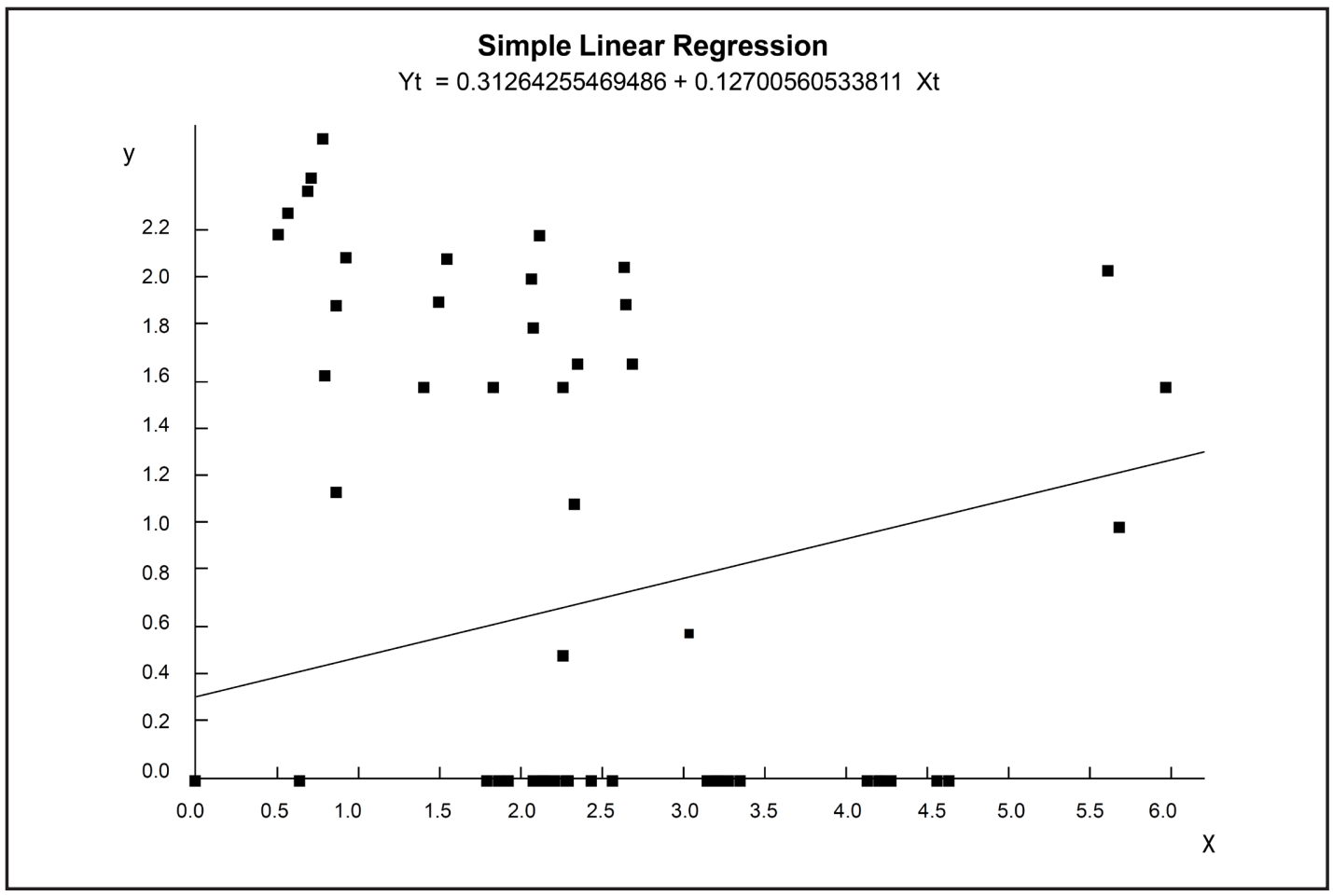

\section{Discussion}

Our knowledge on the consequences related to HBV infection in the dialysis population remains largely incomplete despite important advances in the control of HBV spread within dialysis units [29]. The available information suggests slow progression of HBV-related liver disease in the dialysis population, and various mechanisms have been cited including the virological features of HBV. Only a few and small series of HBsAg positive patients have been evaluated to detect HBV viremia by molecular methods in patients on maintenance dialysis [30-34].

The goal of this study was to assess whether the haemodialysis session itself leads to a reduction in HBV viraemia; to this aim, we have used RealTime PCR technology provided with higher sensitivity than other techniques, as an example bDNA technology, for measuring the viral load of hepatitis B virus (10 IU/mL vs. 2,000 copies/mL, respectively) [27]. Thus, the 


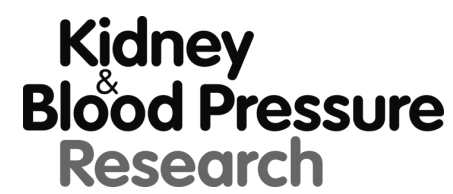

\begin{tabular}{l|l}
\hline Kidney Blood Press Res 2013;37:286-294 \\
\hline DOI: $10.1159 / 000350156$ & $\begin{array}{l}\text { C } 2013 \text { S. Karger AG, Basel } \\
\text { www.karger.com/kbr }\end{array}$ \\
\hline Published online: September 04, 2013 &
\end{tabular}

frequency of chronic HBsAg carriers on long-term dialysis without detectable HBV viremia in serum was lower than that observed in other surveys, $17 \%$ vs. 50\% [18]. HBsAg positive patients with negative results by RealTime PCR technique at the beginning of the study were enrolled as prior evidence showed changes in HBV DNA titers over time with intermittent positive HBV DNA testing [17].

We found that the HD procedure per se leads to a reduction in HBV viral load; this phenomenon occurred irrespective of patient (or dialysis) characteristics or type of dialysis membranes. Our results are in keeping with information coming from other sources concerning HBV [18-20] or HCV [35]. The mechanisms underlying the intradialytic drop in HBV viraemia remain to be clarified. One of the factors for low HBV viral load prior to hemodialysis could be hemodilution as recently observed for alanine aminotransferase levels [36]; however, the data reported in Figure 2 are not in keeping with this. In fact, higher levels of HBV DNA at pre-dialysis phase were found in the first dialysis of the week where the hemodilution effect is much greater than at the midweek or end-of week sessions. The viral half-life that has been calculated for HBV (2-3 days) [37] could play a role in explaining the kinetics of HBV viral load shown in Figure 2.

Some authors described HBV DNA in the dialysate [22-23]; the passage of HBV DNA across the membrane of the dialyzer filter into the spent dialysate was suggested even if the estimated size of HBV particles $(42 \mathrm{~nm})$ does not allow the escape of intact virus through the dialysis membrane into the dialysate. Adsorption of the virus onto the haemodialysis membrane and pressure-dependent destruction could be major potential mechanisms of virus clearance during the haemodialysis procedure, as in HCV [38-39]. The synthesis of various cytokines [40-42] or the removal of factors required for viral production have been also cited to explain the intermittent reduction of HBV viraemia in patients on long-term HD.

Theoretically, the lowered HBV DNA levels at the end of the haemodialysis procedure may be caused by the translocation of the virus into the extravascular compartment during the HD sessions. The shift of body fluids containing HBV virions from the extravascular to the intravascular compartments over the interdialytic period is in keeping with the increase of the HBV load at the beginning of the next HD session, as shown in the current study. The postdialysis rebound of plasma solutes is a relevant drawback of maintenance haemodialysis and is currently an area of active research [43].

The intradialytic changes in IFN- $\alpha$ levels reported in anti-HCV positive patients and thought to be associated with the HCV viral load [25] were not seen in our cohort of HBV-infected patients. We found an increase in IFN- $\alpha$ in a minority of HD procedures only (7.5\%); and no relationship between reduction of HBV viral load and intradialytic kinetics of IFN- $\alpha$ occurred. Our investigation on the kinetics of circulating IFN-alpha in HD patients had preliminary nature- a limited number of HD sessions $(n=40)$ was analyzed, and a semiquantitative analysis was made.

Recent information has shown that the viral load in chronic HBsAg-positive carriers on maintenance dialysis is low [17-19] and relatively stable over years despite the immunodeficiency conferred from chronic uraemia [17]. The intermittent reduction of the viral load and the low number of HBsAg positive/HBeAg positive patients, as listed in our study, support this. Four (17\%) of our patients were repeatedly negative by RealTime PCR technology;. HBsAg positive patients have been recently identified as active carriers in the case of a viral load of $\geq 20,000 \mathrm{IU} / \mathrm{mL}$ in $\mathrm{HBeAg}$ positive and 2,000 IU/mL in $\mathrm{HBeAg}$ negative patients [44].

Our study shows some potential shortcomings. First, we have used RealTime PCR for measuring hepatitis B virus DNA in serum despite heparin is commonly used during haemodialysis sessions in developed countries. It has been suggested that heparin is an unsuitable anticoagulant for plasma DNA analysis because it could inhibit PCR; however, recent data does not confirm this [45]. Second, we noted no impact of various dialysis membranes on the intradialytic reduction of HBV DNA during haemodialysis. Some authors [46] found differences in the kinetics of viral load according to the type of membrane used in HCV positive dialysis patients (i.e., synthetic versus cellulosic membranes). The majority 


\section{Kidney \\ Blood Pressure Research}

of our patients used high-bicompatibility dialysis filters as low-biocompatibility membanes (i.e., cuprophan) are surpassed in developed world; also, the limited number of patients hampered an appropriate comparison. Third, we have not corrected our results on HBV DNA kinetics by fluid loss during dialysis, as performed by others [36]. In fact, when water is extracted during haemodialysis, the plasma becomes concentrated and content in plasma shows higher concentrations reflected in haematocrit increases. The passage of IFN-alpha or hepatitis B virus into the dialysate compartment has not been expected due to the size of the respective molecules. Applying the correction of HBV DNA kinetics by haematocrit increases [21], decreases in HBV DNA viral load should become more pronounced, while increases smaller or disappeared.

We detected no PC/ BCP mutations by Line Probe Assay technique. The low HBV viral load in our series could explain this- in fact, recent data suggest a significant relationship between high HBV viral load and frequency of PC/BCP mutations in chronic hepatitis B [47]. We tested a small number of patients and this precludes more definitive conclusions.

\section{Conclusion}

We observed that the hemodialysis procedure per se lowers HBV DNA levels and the intradialytic kinetics of IFN- $\alpha$ is not apparently responsible of this phenomenon. Although other mechanisms cannot be excluded, we suggest that the intermittent reduction of HBV viremia in patients on long-term haemodialysis is implicated in the mild course of hepatitis B-related liver disease in this population.

\section{Acknowledgements}

The authors' work is supported in part by the grant 'Project Glomerulonephritis'; in memory of Pippo Neglia.

\section{References}

1 Finelli L, Miller JT, Tokars JI, Alter MJ, Arduino MJ: National surveillance of dialysis-associated diseases in the United States, 2002. Semin Dial 2005;18:52-61.

-2 Burdick RA, Bragg-Gresham JL, Woods JD, Hedderwick SA, Kurokawa K, Combe C, Saito A, La Bracque J, Port FK, Young EW: Patterns of hepatitis B prevalence and seroconversion in hemodialysis units from three continents: the DOOPS. Kidney Int 2003;63:2222-2229.

-3 Inoue K, Ogawa O, Yamada M, Watanabe T, Okamoto H, Yoshiba M: Possible association of vigorous hepatitis B virus replication with the development of fulminant hepatitis. J Gastroenterol 2006;41:383-387.

-4 Kondili LA, Genovese D, Argentini C, Chionne P, Toscani P, Fabro R, Cocconi R, Rapicetta M: Nosocomial transmission in simultaneous outbreaks of hepatitis $\mathrm{C}$ and $\mathrm{B}$ virus infections in a haemodialysis center. Eur J Clin Microbiol Infect Dis 2006;25:527-531.

5 Voiculescu M, Iliescu L, Ionescu C, Micu L, Ismail G, Zilisteanu D, Radasan A, Micu G, Pertache I: A crosssectional epidemiological study of HBV, HCV, HDV, and HEV prevalence in the SubCarpathian and SouthEastern regions of Romania. J Gastrointestin Liver Dis 2010;19:43-48.

-6 Johnson DW, Dent H, Yao Q, Tranaeus A, Huang CC, Han DS, Jha V, Wang T, Kawaguchi Y, Qian J: Frequencies of hepatitis B and C infections among haemodialysis and peritoneal dialysis patients in Asia-Pacific countries: analysis of registry data. Nephrol Dial Transplant 2009;24:1598-1603.

7 Ferreira RC, Teles SA, Dias MA, Tavares VR, Silva SA, Gomes SA, Yishida CF, Martins RM: Hepatitis B virus profile in hemodialysis patients in Central Brazil: prevalence, risk factors, and genotypes. Mem Inst Oswaldo Cruz 2006;101:689-692. 


\section{Kidney \\ Blood Pressure Research}

8 Chandra M, Khaja MN, Hussain MM, Posuri CD, Fares N, Habeb MA, Krishnan S, Ramareddy GV, Habibullah CM: Prevalence of hepatitis B and hepatitis C viral infections in Indian patients with chronic renal failure. Intervirology 2004;47:374-376.

-9 Qadi AA, Tamim H, Ameen G, Bu-Ali A, Al-Arrayed S, Fawaz NA, Almawi WY: Hepatitis B and hepatitis C virus prevalence among dialysis patients in Bahrain and Saudi Arabia: A survey by serologic and molecular methods. Am J Infection Control 2004;32:493-495.

10 Marcelli D, Stanhard D, Conte F, Held PJ, Locatelli F, Port FK: ESRD patients mortality with adjustment for comorbid conditions in Lombardy (Italy) versus the United States. Kidney Int 1996;50:1013-1018.

11 Maisonneuve P, Agodoa L, Gellert R, Stewart JH, Buccianti G, Lowenfels AB, Wolfe RA, Jones E, Disney AP, Briggs D, McCredkie M, Boyle P: Cancer in patients on dialysis for end-stage renal disease: an international and collaborative study. Lancet 1999;354:93-99.

$\checkmark 12$ Josselson J, Kyser BA, Weir MR, Sadler JH: Hepatitis B surface antigenemia in a chronic hemodialysis program: lack of influence on morbidity and mortality. Am J Kidney Dis 1987;6:456-461.

13 Jha R, Kher BA, Naik S, Elhance R, Gupta A, Sharma RK: Hepatitis B associated liver disease in dialysis patients: role of vaccination. J Nephrol 1993;6:98-103.

14 Lezaic V, Stosovic M, Marinkovic J, Rangelov V, Djukanovic L: Hepatitis B and hepatitis C virus infection and outcome of haemodialysis and kidney transplant patients. Ren Fail 2008;30:81-87.

15 Deschamps-Latscha B, Herbelin A: Long-term dialysis and cellular immunity: A critical survey. Kidney Int 1993;41:S135-S142.

16 Moutinho RS, Perez RM, Median-Pestana JO, Figueredo MS, Koide S, Lopes Alberto F, Silva AEB, Ferraz MLG: Low HBV DNA levels in end-stage renal disease patients with HBeAg-negative chronic hepatitis B. J Med Virol 2006;78:1284-1288.

17 Fabrizi F, Lunghi G, Alongi G, Bisegna S, Campolo G, Mangano S, Limido A, Pagliari B, Tettamanzi F, Ponticelli C: Biological dynamics of hepatitis B virus load in dialysis population. Am J Kidney Dis 2003;41:1278-1285.

18 Fabrizi F, Lunghi G, Alongi G, Aucella F, Barbisoni F, Bisegna S, Corghi S, Faranna P, Mangano S, RomeiLonghena G, Martin P: Kinetics of hepatitis B virus load and haemodialysis: a prospective study. J Viral Hepatitis 2008;15:917-921.

19 Tseng G, Lin H, Fang C, Cheng Y, Huang C, Tseng G, Wang P, Hung T, Yang K: Hemodialysis reduces the viral load in uremic patients with chronic hepatitis B infection. Renal Failure 2008;30:1000-1005.

20 Tseng G, Yang K: Kinetics of hepatitis B virus load and haemodialysis: a prospective study. J Viral Hepatitis 2009;16:298.

21 Mederacke I, Meier M, Luth J, Schmidt-Gurtler H, Raupach R, Horn-Wichmann R, Wursthorn K, Potthoff A, Colucci G, Manns M, Wedemeyer H, Tillmann H: Different kinetics of HBV and HCV during haemodialysis and absence of seronegative viral hepatitis in patients with end-stage renal disease. Nephrol Dial Transplant 2010;26:2648-2656.

22 Kroes ACM, van Bommel EFH, Niesters HGM, Weimar W: Hepatitis B viral DNA detectable in dialysate. Nephron 1994;67:369.

23 Moynot A, Lazizi Y, Dubreil P, Buisson C, Pillot J: Nature of HBsAg ultrafiltrate of haemodialysed patients: Presence of viral DNA. Nephrol Dial Transplant 1988;49:88.

24 Salo JR, Salo AA, Fahlberg WJ, Ellzey JT: Hepatitis B surface antigen in peritoneal fluid of HBsAg carriers undergoing peritoneal dialysis. J Med Virol 1980;6:29-35.

25 Badalamenti S, Catania A, Lunghi G, Covini G, Bredi E, Brancaccio D, Salvadori M, Como G, Ponticelli C, Graziani G: Changes in viremia and circulating interferon-alpha during hemodialysis in hepatitis $\mathrm{C}$ virus positive patients: only coincidental phenomena ? Am J Kidney Dis 2003;42:143-150.

26 Rampino T, Arbustini E, Gregorini M, Guallini P, Libetta C, Maggio M, Ranghino A, Silini E, Soccio G, Dal Canton A: Hemodialysis prevents liver disease caused by hepatitis $\mathrm{C}$ virus. Role of hepatocyte growth factor. Kidney Int 1999;56:2286-2291.

27 Thibault V, Pichoud C, Mullen C, Rhoads J, Smith J, Bitbol A, Thamm S, Zoulim F: Characterization of a new sensitive PCR assay for quantification of viral DNA isolated from patients with hepatitis B virus infection. J Clin Microbiol 2007;45:3948-3953.

28 Abbott RealTime HBV Assay (Package Insert), Abbott Laboratories, Illinois, USA. Available at: http://www. abbottmolecular.com/us/realtime. Accessed September 4, 2010.

-29 Urbanek P: Viral hepatitis infections in chronic kidney disease patients and renal transplant recipients. Kidney Blood Pressure Res 2012;35:454-467. 


\section{Kidney \\ Blood Pressure Research}

30 Dueymes JM, Bodenes-Dueymes M, Mahè JL, Herman B: Detection of hepatitis B viral DNA by polymerase chain reaction in dialysis patients. Kidney Int 1993;41:S161-S166.

-31 Pao CC, Yang WL, Huang CC, Hsu JL, Lin SS, Ken R, Chao Y, Sun CF, Liaw YF, Lin JY: Hepatitis type B virus DNA in patients receiving hemodialysis: correlation with other HBV serological markers. Nephron 1987;46:155-160.

-32 Oesterreicher C, Hammer J, Koch U, Pfeffel F, Sunder-Plassmann G, Petermann D, Muller C: HBV and HCV genome in peripheral blood mononuclear cells in patients undergoing chronic hemodialysis. Kidney Int 1995;48:1967-1971.

33 Cabrerizo M, Bartolomè J, De Sequera P, Caramelo C, Carreno V: Hepatitis B virus DNA in serum and blood cells of hepatitis B surface antigen-negative hemodialysis patients and staff. J Am Soc Nephrol 1997;8:1443-1447.

34 Cabrerizo M, Bartolomè J, Caramelo C, Barril G, Carreno V: Molecular analysis of hepatitis B virus DNA in serum and peripheral blood mononuclear cells from hepatitis B surface antigen-negative cases. Hepatology 2000;32:1116-1123.

-35 Kaiser T, Damerow H, Tenckhoff S, Finger A, Bottcher I, Hafer C, Scwarz A, Luth J, Gurtler H, Colucci G, Manns M, Wedemeyer H, Tillmann H: Kinetics of hepatitis C viral RNA and HCV antigen during dialysis sessions: Evidence for differential viral load reduction on dialysis. J Med Virol 2008;80:1195-1201.

-36 Lopes EP, Sette LH, Sette JB, Luna CF, Andrade AM, Moraes M, Sette PC, Menezes R, Cavalcanti RL, Conceicao SC: Serum alanine aminotransferase levels, hematocrit rate and body weight correlations before and after hemodialysis session. Clinics (Sao Paulo) 2009;64:941-945.

-37 Zeuzem S, de Man R, Honkoop P, Roth W, Schalm S, Schmidt J: Dynamics of hepatitis B virus infection in vivo. J Hepatol 1997;27:431-436.

-38 Noiri E, Nakao A, Oya A, Fujita T, Kimura S: Hepatitis C virus in blood and dialysate in hemodialysis. Am J Kidney Dis 2001;37:38-42.

39 Mizuno M, Higuchi T, Yanai M, Kanmatsuse K, Esumi M: Dialysis-membrane dependent reduction and adsorption of circulating hepatitis C virus during hemodialysis. Nephron 2002;91:235-241.

40 Rostaing L, Peres C, Tkaczuk J, Charlet JP, Bories P, Durand D, Ohayon E, de Preval C, Abbal M: Ex vivo flow cytometry determination of intracytoplasmic expression of IL-2, IL-6, IFN-gamma and IFN alpha in monocytes and T-lymphocytes in chronic haemodialysis patients. Am J Nephrol 2000;20:18-26.

41 Malaponte G, Bevelacqua V, Fatuzzo P, Rapisarda F, Emmanuele G, Travali S, Mazzarino MC: IL-1 $\beta$, IFN- $\alpha$ and IL-6 release from monocytes in haemodialysis patients in relation to dialytic age. Nephrol Dial Transplant 2002;17:1964-1970.

42 Rostaing L, Chatelut E, Payen JL, Izopet J, Thalamas C, Ton-That H, Pascal JP, Durand D, Canal P: Pharmacokinetics of $\alpha$-IFN in chronic hepatitis $C$ virus undergoing chronic hemodialysis or with normal renal function: Clinical implications. J Am Soc Nephrol 1998;9:2344-2348.

43 Di Filippo S, Pozzoni P, Manzoni C, Andrulli S, Pontoriero G, Locatelli F: Relationship between urea clearance and ionic dialysance determined using a single-step conductivity profile. Kidney Int 2005;68:2389-2395.

44 Marzano A, Angelucci E, Andreone P, Brunetto M, Bruno R, Burra P, Caraceni P, Daniele B, Di Marco V, Fabrizi F, Fagiuoli S, Grossi P, Lampertico P, Meliconi R, Mangia A, Puoti M, Raimondo G, Smedile A: for the Italian Association for the Study of the Liver (AISF): Prophylaxis and treatment of hepatitis B in immunocompromised patients. Dig Liver Dis 2007;39:397-408.

45 Lam N, Rainer T, Chiu R, Lo YM: EDTA is a better anticoagulant than heparin or citrate for delayed blood processing for plasma DNA analysis. Clin Chem 2004;50:256-257.

46 Angelico M, Morosetti M, Passalacqua S, Chiappini MG, Botta S, Ombres D, Splendiani G, Casciani CU: Low levels of hepatitis $\mathrm{C}$ virus RNA in blood of infected patients under maintenance haemodialysis with highbiocompatibility, high-permeability filters. Digest Liver Dis 2000;32:724-728.

47 Ghabeshi S, Sharifi Z, Hosseini S, Shooshtari M: Correlation between viral load of HBV in chronic hepatitis B patients and precore and basal core promoter mutations. Hepat Mon 2013;13:e7415. 